\title{
Why Breach of Contract May Not be Immoral Given the Incompleteness of Contracts
}

\section{Citation}

Steven M. Shavell, Why Breach of Contract May Not be Immoral Given the Incompleteness of Contracts, 107 Mich. L. Rev. 1569 (2009).

\section{Published Version}

http://www.michiganlawreview.org/assets/pdfs/107/8/shavell.pdf

\section{Permanent link}

http://nrs.harvard.edu/urn-3:HUL.InstRepos:12027856

\section{Terms of Use}

This article was downloaded from Harvard University's DASH repository, and is made available under the terms and conditions applicable to Open Access Policy Articles, as set forth at http:// nrs.harvard.edu/urn-3:HUL.InstRepos:dash.current.terms-of-use\#OAP

\section{Share Your Story}

The Harvard community has made this article openly available.

Please share how this access benefits you. Submit a story.

Accessibility 


\title{
WHY BREACH OF CONTRACT MAY NOT BE IMMORAL GIVEN THE INCOMPLETENESS OF CONTRACTS
}

\author{
Steven Shavell*
}

There is a widely held view that breach of contract is immoral. I suggest here that breach may often be seen as moral, once one appreciates that contracts are incompletely detailed agreements and that breach may be committed in problematic contingencies that were not explicitly addressed by the governing contracts. In other words, it is a mistake generally to treat a breach as a violation of a promise that was intended to cover the particular contingency that eventuated.

There is a widely held view that breach of contract is immoral. ${ }^{1}$ Yet it is manifest that legal systems ordinarily do allow breach - the law usually permits breach if the offending party pays damages ${ }^{2}$ - and it is a commonplace that breach occurs. Thus, a tension exists between the felt sense that wrong has been done when contracts are broken and the actual operation of the law. This opposition has long been remarked by commentators. ${ }^{3}$

Recently I wrote on the question of when breach of contract should be considered immoral. ${ }^{4}$ My primary point was that breach may often be seen as moral once one appreciates that contracts are incompletely detailed

* Samuel R. Rosenthal Professor of Law and Economics, Harvard Law School. I thank Louis Kaplow for comments and the John M. Olin Center for Law, Economics, and Business for research support.

1. See, e.g., Restatement (Second) of Contracts ch. 16, introductory note at 100 (1981); Charles Fried, Contract as Promise: A Theory of Contractual Obligation 17 (1981); Tess Wilkinson-Ryan \& Jonathan Baron, Moral Judgment and Moral Heuristics in Breach of Contract, 6 J. Empirical Legal Stud. (forthcoming 2009) (an empirical study).

2. Restatement (Second) of Contracts ch. 16, introductory note at 100 (1981) ("The traditional goal of the law of contract remedies has not been compulsion of the promisor to perform his promise but compensation of the promisee for the loss resulting from breach."); see also JoHN D. Calamari \& Joseph M. Perillo, The Law of Contracts $\$ 16.1$ (4th ed. 1998) ("The primary relief that the Anglo-American legal systems offer is substitutionary relief, normally damages .... Specific performance is an extraordinary remedy ....”).

3. E.g., O.W. Holmes, The Path of the Law, 10 Harv. L. Rev. 457, 462 (1897) ("The duty to keep a contract ... means ... that you must pay damages if you do not keep it .... But such a mode of looking at the matter stinks in the nostrils of those who think it advantageous to get as much ethics into the law as they can.").

4. Steven Shavell, Is Breach of Contract Immoral?, 56 EMORy L.J. 439 (2006) [hereinafter Shavell, Is Breach of Contract Immoral?]. Many of the points of that article are first made in Steven Shavell, Damage measures for breach of contract, 11 BeLL J. ECON. 466, 466-69 (1980) [hereinafter Shavell, Damage measures], and are amplified in Louis Kaplow \& STEVen Shavell, Fairness Versus Welfare 155-223 (2002). See also Steven Shavell, Foundations of Economic AnalYSIS OF LAW 304-12, 338-55, 638-40 (2004). 
agreements and that breach may be committed in problematic contingencies that were not explicitly addressed by the governing contracts. In other words, because of contractual incompleteness, it is a mistake generally to treat a breach as a violation of a promise that was intended to cover the particular contingency that eventuated.

Seana Shiffrin has critically examined my analysis of the immorality of breach in her symposium contribution. ${ }^{5}$ I here want to respond to hermainly to disagree, but partly to agree. I will first review my prior argument and then will comment on Shiffrin.

\section{Summary of the Argument that Breach May Not Be IMMORAL GIVEN THE INCOMPLETENESS OF CONTRACTS ${ }^{6}$}

\section{A. Definition of Moral Behavior in a Contingency ${ }^{7}$}

To discuss the immorality of breach, one must, of course, state what constitutes moral behavior in the contractual context. I make two simple definitional assumptions. First, I presume that if a contract provides explicitly for a contingency, then the moral duty to perform in that contingency is governed by the contract. Second, I suppose that if a contract is incomplete in the sense that it does not provide explicitly for a contingency, then the moral duty to perform in the contingency is governed by what a completely detailed contract addressing the contingency would have stipulated, assuming that the parties know what this hypothetical contract would have stated. ${ }^{8}$

Consider, for example, a contract concerning the clearing of snow from a person's driveway and the contingency that the seller's snow clearing equipment is stolen. ${ }^{9}$ Suppose that the contract specifies that if such a theft occurs, the seller still has an obligation to clear snow (perhaps because he can readily rent snow clearing equipment). Then the seller is assumed to have a moral duty to clear snow even if his equipment is stolen. However, if the contract mentions the possibility of theft and says that in that event the seller does not have to clear snow (perhaps because it would be very difficult to rent substitute equipment on the spot), then the seller would not have a moral duty to perform should his equipment be stolen. And, if the contract

5. Seana Shiffrin, Could Breach of Contract Be Immoral?, 107 Mich. L. Rev. 1551 (2009) [hereinafter Shiffrin, Breach of Contract]; see also Seana Valentine Shiffrin, The Divergence of Contract and Promise, 120 HaRv. L. Rev. 708 (2007).

6. I here sketch the argument of Shavell, Is Breach of Contract Immoral?, supra note 4.

7. This section is reprinted with permission of the Emory Law Journal, and appeared in part in Shavell, Is Breach of Contract Immoral?, supra note 4.

8. In reality, what a contract would have said about a particular contingency might not be known with confidence by the parties, implying that they might not know their moral duties with confidence.

9. In this example, taken from Shavell, Is Breach of Contract Immoral?, supra note 4, at 443 , and below, I will refer to the party who would provide performance as the seller (rather than the promisor) and to the party who would receive performance as the buyer (rather than the promisee). 
does not mention the contingency of theft explicitly, the seller's obligation to clear snow in that circumstance would be determined by what a hypothetical complete contract would have said, assuming that the parties know its nature.

The appeal of the foregoing definition of moral obligation derives from the observation that a contract that provides explicitly for a contingency is similar to a promise that provides explicitly for a contingency, and that there are well known grounds for finding that individuals have moral obligations to keep such promises. ${ }^{10}$ I will return to the subject of the appeal of my definition of moral obligation in the contractual domain in Part II. For the remainder of this Part, I put that matter to the side and develop the implications of my definition.

\section{B. The Observed Incompleteness of Contracts}

That the definition of moral obligation applies when contracts do not explicitly mention the contingency that arose is important because this may well be the state of affairs. We see that in reality contracts are far from completely detailed. Although a contract for removing snow from a person's driveway might mention a number of conditions, for instance whether clearing is to be done on Christmas day, it will typically omit a practically endless number of events that could matter to the seller-theft of his snowclearing equipment, illness of his crew, snow so deep that it makes roads impassable - or to the buyer-unexpected travel out of town over the winter, sale of her home, inheritance of snow clearing equipment.

It is true that contracts will often provide implicitly for many, and perhaps all, contingencies. "Suppose that a contract states that 'snow is to be cleared from the buyer's driveway if the snow is over five inches deep,' and that the contract mentions no other conditions." ${ }^{11}$ This contract implicitly covers the contingency of theft because "in a formal sense the contract covers all contingencies: it divides them into two general categories, those in which the snow is up to five inches deep (whatever else happens), and those in which the snow is over five inches deep (whatever else happens)." But because the contract does not mention theft explicitly, I consider the contract to be incomplete as to that contingency.

Why are contracts substantially incomplete in that they omit explicit mention of numerous contingencies? Most obviously, it is because time is needed to discuss and to include contingent provisions in contracts. If a contingency like theft of snow clearing equipment is sufficiently unlikely, the probability-discounted benefit of providing for it in the contract will be low

10. See, e.g., David Hume, A Treatise of Human Nature $\S 3.2 .5$ (David Fate Norton \& Mary J. Norton eds., Oxford Univ. Press 2007) (1739); Immanuel Kant, Groundwork of the Metaphysics of Morals 15, 32, 38 (Mary Gregor ed. \& trans., Cambridge Univ. Press 1997) (1785); W.D. Ross, The RIGHT AND THE Good 16-47 (Philip Stratton-Lake ed., 2002) (1930); John Rawls, Two Concepts of Rules, 64 PHIL. Rev. 3 (1955).

11. This example is taken from Shavell, Is Breach of Contract Immoral?, supra note 4, at 446-47. 
and will be outweighed by the cost of the time that would be spent to do so. Other significant reasons for contractual incompleteness are that a contingency (such as whether a person had a stomachache) might be hard for a court to verify, which would make a clause depending on its occurrence unworkable; that parties might be able to renegotiate if a problematic circumstance arises; and that parties might be able to commit breach and pay damages if a difficulty arises. In all, then, the existence of significant contractual incompleteness is not surprising.

\section{The Morality of Breach When Contracts Are Incomplete}

Given the importance of incompleteness of contracts, we know that questions about the morality of breach will often concern situations in which the contingency that occurred was not specifically mentioned in the contract. If a snow clearing company breaches its contract to clear my driveway when its equipment was stolen but the contract did not explicitly address that contingency, we cannot assess the morality of the breach by pretending that the contract did address the contingency (in which case the breach would be immoral by hypothesis). We must engage in further inquiry. To determine whether the breach was moral under my definition, we have to ascertain "whether performance would ... have been required had the contingency been expressly addressed" in the contract, that is, we need to understand the character of hypothetical complete contracts. ${ }^{12}$

\section{The Nature of Obligations to Perform in Hypothetical Completely Detailed Contracts}

We can deduce a very important characteristic about the nature of a hypothetical complete contract agreed upon by rational parties. Namely, performance will be required in a "contingency if and only if the cost [of performance to the seller] ... would be less than the value of performance to the buyer." ${ }^{\prime 3}$

The logic leading to this conclusion is that if the contract were otherwise, it could always be altered in a way that both parties would preferhence they would never settle on a contract unless it were of the claimed type. To illustrate, suppose in our snow clearing example that the buyer and the seller consider a contract that calls for performance in a contingency in which the cost of performance to the seller would be $\$ 300$ and would exceed the value to the buyer of $\$ 100$. Thus the contemplated contract is different from the claimed type. Let the contemplated contract be changed only in the term covering this contingency: under the adjusted contract, the snow does not have to be cleared, and the seller must make a payment to the buyer of $\$ 110$ (in addition to whatever other payment might have been stipulated in the contemplated contract). Clearly, the buyer would be better

12. Id. at 448

13. Id. at 444-45. 
off in the contingency at issue under the new contract, for she would receive, in the $\$ 110$ payment, more than the $\$ 100$ value she would lose from not having snow removed. Likewise, the seller would be better off in the contingency because his payment of $\$ 110$ would be less than his cost savings of $\$ 300$ from not having to perform. Because both parties would be better off in the contingency in question and would be just as well off in all other contingencies (because the new contract does not change in those contingencies), both parties would prefer the new contract to the contemplated one. Hence, they would never agree to the contemplated contract calling for performance when the cost would exceed the value of performance. Similar logic shows that the parties would never agree to a contract in which there is a contingency not calling for performance even though its cost would be less than its value. ${ }^{14}$

The conclusion just discussed validates what should be appealing to the intuition in a qualitative sense. One would expect that if the parties were bargaining over each contingency individually, they would agree on performance when it would not be very expensive for the seller relative to its value to the buyer but agree that it is not worthwhile to specify performance when its cost for the seller would be high.

\section{E. The Immorality or Morality of Breach When Contracts Are Incomplete Can Be Inferred from the Willingness of the Party in Breach to Pay Damages ${ }^{15}$}

If there is a breach in a contingency that was not provided for, such as theft of snow clearing equipment, how can we ascertain whether, had they discussed that contingency explicitly, the parties would have agreed that there would or would not be an obligation to perform?

We know from Section I.D that the answer inheres in whether the cost of performance was less than its value. If that is so, then the parties would have specified performance and the breach would thus be immoral; if that is not so, and the cost would have exceeded the value of performance, the breach would not be immoral. Must we make a direct inquiry about the cost and the value of performance to know whether the breach was immoral? The answer is no.

We can draw an inference about the cost of performance if the breaching party paid damages for breach. We know that the party in breach must have considered the cost of performance to be greater than the damage amount. In particular, suppose that the measure of damages is the expectation, that is, the value of performance to the buyer. Then a seller will commit breach if

14. Although this paragraph demonstrates that the conditions under which performance is specified must be as claimed, it does not show what the contract price or possible payments made in the event of nonperformance would be. These elements of the contract would depend on characteristics of the parties and cannot be predicted on a priori grounds.

15. This section is reprinted with permission of the Emory Law Journal, and appeared in part in Shavell, Is Breach of Contract Immoral?, supra note 4. 
and only if his cost of performance would exceed the value of performance. In the snow clearing contract, suppose that the value of performance to the buyer is $\$ 200$. Then if the seller breaches after his equipment is stolen and pays expectation damages, we infer that his cost of performance exceeded $\$ 200 .^{16}$ Because the cost exceeds the value, this implies that had the parties discussed the theft contingency, they would have agreed that there would be no duty to perform in that event. Thus, the seller's breach and failure to clear snow when his equipment is stolen is not immoral; his behavior is precisely in accord with what would have been the terms of a completely detailed contract that spoke to the circumstance - the theft of snow clearing equipment-that actually occurred.

This example illustrates the general point that when the measure of damages equals the expectation, a seller will be led to breach if and only if the cost of performance exceeds the value of performance to the buyer. Because that is exactly when a seller would not have to perform in a completely detailed contract, the seller will fail to perform in the same contingencies as the seller would be permitted not to perform in a hypothetical complete contract. Accordingly, breach should not be characterized as immoral when expectation damages are paid for breach. ${ }^{17}$

Now assume that damages for breach are less than the expectation. Because breach will tend to occur whenever the cost of performance exceeds the level of damages, breach will occur more often than nonperformance would have been permitted in a completely specified contract- thus breach might be immoral. In our example, if the measure of damages were, say, $\$ 50$ instead of the expectation of $\$ 200$, breach would occur whenever the cost of performance would exceed $\$ 50$. Consequently, if breach occurred when the cost would be between $\$ 50$ and $\$ 200$, the complete contract would have insisted on performance. Such breach would be immoral. ${ }^{18}$

\section{F. When Is Breach Immoral and When Is it Moral in Practice? ${ }^{19}$}

Given the conclusions just reached, we can say that if damages equal the buyer's expectation, breach can be inferred to be moral because it will occur only when the parties would have allowed nonperformance in a complete contract. However, when damages are less than the expectation, we cannot

16. To amplify, suppose that the contract price is paid in advance. Then expectation damages would equal $\$ 200$, for that amount must be received by the buyer to make her whole. Consequently, the seller would not commit breach unless the cost exceeded \$200. Alternatively, suppose that the contract price, say $\$ 125$, is to be paid upon performance. Then expectation damages would equal $\$ 75$, for now it is this amount that must be received to make the buyer whole. Hence, if the seller commits breach, he forgoes collecting the $\$ 125$ and pays $\$ 75$, and so suffers a total cost of $\$ 200$; again, therefore, he would not commit breach unless the cost exceeded $\$ 200$.

17. Shavell, Is Breach of Contract Immoral?, supra note 4, at 449.

18. Id. at 450 .

19. This section is reprinted with permission of the Emory Law Journal, and appeared in part in Shavell, Is Breach of Contract Immoral?, supra note 4. 
make this inference and would have to inquire directly about the cost of performance relative to its value in order to make a judgment about its morality.

Are damages fully compensatory? They are intended to be. The expectation measure is, of course, the general damage remedy employed for breach of contract, where the expectation measure is defined as the amount that would restore the victim of a breach to the position that this party would have enjoyed had there been performance. ${ }^{20}$ The expectation measure as it is actually applied, however, tends to be less than fully compensatory and may leave the victim of a breach substantially worse off than he or she would have been had there been performance. ${ }^{21}$ The reasons given for believing that the expectation measure is often undercompensatory include the following. First, courts are reluctant to credit hard-to-measure components of loss as damages. Hence, lost profits and idiosyncratic losses due to breach are likely to be inadequately compensated or neglected. Second, courts are inclined to limit damages to those that could have been reasonably foreseen at the time the contract was made. Third, damages tend not to reflect the considerable delays that victims of breach may suffer. Fourth, legal costs are not compensated.

Not only do expectation damages appear to be undercompensatory in a general sense, but damages for breach may be effectively nonexistent if the breach victim's losses are less than the costs of bringing suit, which is to say, are below a threshold of several thousand dollars. If the losses are not this high, the breach victim will not have a credible threat to litigate. ${ }^{22}$

In view of these remarks about the adequacy of damages, the practical reality is that breach will often be of suspect moral quality, and the likelihood that breach is immoral will be higher the lower are damages in relation to the true expectation.

\section{Criticism ANd Discussion of the Foregoing Argument}

Seana Shiffrin makes three criticisms of the argument that I have summarized. The first is that she disputes my conclusion that the hypothetical complete contract would be as I asserted-calling for performance when and only when its cost is less than its value. The second criticism is that she does not find that the hypothetical complete contract provides an appealing moral standard for the obligation to perform. The third criticism is that she believes that performance per se should possess a positive moral valence, whereas performance does not have this character in my framework. After

20. Restatement (Second) of Contracts § 346-47 (1981); Calamari \& Perillo, supra note $2, \S 14.4$.

21. A good account of why damages are undercompensatory is given in Melvin A. Eisenberg, Actual and Virtual Specific Performance, the Theory of Efficient Breach, and the Indifference Principle in Contract Law, 93 CAL. L. REv. 975, 989-96 (2005).

22. If, for example, a lawyer's hourly fee is $\$ 250$, and only twenty hours of his or her time are required to litigate, the legal costs of litigation would be $\$ 5000$, implying that the expected gain from suit would have to exceed this amount for a threat to litigate to be credible. 
discussing these criticisms, I consider the issue of how to choose among different definitions of moral behavior in the contractual context.

\section{A. The Nature of the Hypothetical Complete Contract}

Shiffrin appears to have misunderstood an assumption that I made concerning the hypothetical complete contract. I presumed that each contingent provision in a hypothetical complete contract calling for performance would definitely be enforced-so that such a contract means exactly what it says. For simplicity, I also presumed that if a contingent provision does not call for performance, no payment would be made by the seller if that contingency arose. ${ }^{23}$ In contrast, Shiffrin seems to have thought that under the hypothetical complete contract, breach was permitted if a person paid damages. $^{24}$

In any event, and more importantly, Shiffrin questions the central claim that the agreed terms of the hypothetical contract would specify performance in a contingency if and only if its cost to the seller is less than its value to the buyer. In fact, the claim is correct-it is an objective claim that follows from straightforward logic and is a standard point in the economic literature on contracts. ${ }^{25}$ The example I provided of the argument for the claim in Section I.D is essentially a general proof. It shows that if any term in a proposed contract does not have the asserted character, an altered contract with that term changed in the claimed way can be devised such that both the buyer and the seller prefer the new contract. Indeed, this argument explains why a surmise of Shiffrin is incorrect. She suggests that the claim might not hold if one were to take into account bargaining over all the terms of the contract. ${ }^{26}$ But the argument does not depend on the other terms in the contract. The argument shows that by adjusting only the term applying in a single contingency, both parties will be made better off regardless of what the other terms might have been.

23. I considered hypothetical completely detailed contracts in Shavell, Is Breach of Contract Immoral?, supra note 4, at 444-46. The discussion and calculations there are premised on the assumption that performance occurs when a contract states that it is to occur. Breach and payment of damages are never mentioned and play no role in the hypothetical complete contract.

24. Shiffrin, Breach of Contract, supra note 5, at 1557-59, speculates on what the hypothetical complete contract means. She conjectures that the parties would have elected terms that "provided the promisor with a disjunctive option to perform or pay expectation damages. I suspect that ... this is the correct interpretation of [Shavell's] position." Id. at 1558-59. As I just stated in the text and in the preceding note, that was not my assumption. Also, I observe that had I made a different definition of the hypothetical contract, under which nonperformance would be accompanied by the payment of money by the seller, my conclusion about the agreed upon conditions of performance would be the same. Indeed, the argument given in Section I.D demonstrates this.

25. See, e.g., Benjamin E. Hermalin et al., Contract Law, in 1 HandbooK of LAw AND Economics 3, 24-25 (A. Mitchell Polinsky \& Steven Shavell eds., 2007); Shavell, Damage measures, supra note 4, at 475-76.

26. Shiffrin, Breach of Contract, supra note 5, at 1559 ("Shavell fails to contemplate the entire contract and its contents. He focuses on how the contingency would have been settled in isolation."). 


\section{B. Does the Hypothetical Complete Contract Provide an Appealing Moral Standard?}

Shiffrin questions the appeal of my definition of the moral obligation to perform. She asks, "[i]s he right to assert that there is a moral duty to perform only if the parties would have explicitly agreed to perform had they squarely faced the contingency that is the occasion for the breach?"27

However, she does not address head on the attraction of my definition of moral obligation. That is, if the parties to the contract know what they would have provided for in an express provision for the contingency that actually occurred-and they did not make the express provision only because of some practical reason-one would think their moral duty would be governed by the agreement that they would have made but for this practical reason. Suppose that the buyer and the snow clearer signed a contract reading simply that "snow clearer shall clear buyer's snow from her driveway"; that they both understand that had their contract mentioned theft of equipment, the clearer would not have to remove snow; and that they did not include a provision mentioning theft because they did not feel it was worth the trouble given the unlikelihood of theft. Realizing all of this, why would the buyer feel that the clearer has a moral obligation to remove snow if his equipment had been stolen, and why would the clearer feel such an obligation? It is not apparent to me that either the buyer or the seller would feel that the seller had an obligation to perform. An obligation could only be felt, I think, if the parties mistakenly conflate the incomplete contract reading "snow clearer shall clear buyer's snow from her driveway" with an explicit agreement intended to cover theft of snow clearing equipment.

Instead, among other things, Shiffrin emphasizes an issue that I did not discuss and imputes to me a view about it that I do not hold. She considers the possibility that one party to a contract might have superior information to the other. ${ }^{28}$ If this is so, she intimates that the party with superior knowledge could enjoy an unfair advantage if his moral obligation is determined by the hypothetical complete contract. For instance, if the snow clearer knows his equipment is likely to be stolen and the buyer does not, the buyer might be led to pay too much for the contract. I did not address such issues of asymmetry of information because they are collateral to the main point of interest for us. ${ }^{29}$ Had I considered asymmetry of information, I would have

27. Id. at 1560 .

28. Shiffrin states her position as follows:

$[\mathrm{O}]$ ne may be tempted by the thought that . . . one party should bear the burden for not raising the contingency and ushering the parties to a concrete explicit bargain. In the case of the contract for snow removal, for example, the risks and costs of equipment failure are more salient to the promisor than to the promisee .... One might presume . . . that he bears default responsibility for performance in this contingency; or at the very least . . . for drawing attention to the issue.

Id. at $1560-61$.

29. To understand the morality of breach, it is clarifying to focus on a contractual context uncluttered by, not only issues of unequal information, but a whole host of others (duress, mitiga- 
analyzed the moral obligation to disclose information at the time of contracting, as well as to perform, ${ }^{30}$ and my conclusions about the moral obligation to perform in the absence of disclosure would be different.

Shiffrin also suggests that one of the main implications of my viewthat committing breach and paying expectation damages is morally permissible-violates her moral intuition. She finds it counterintuitive, offensive to her sense of right and wrong, that a party can breach and pay such damages. "So long as $A$ would rather just pay expectation damages than perform, does that mean $A$ does no moral wrong if she decides not to perform?" ${ }^{31}$ My reaction to this view is twofold. First, as I explained in Section I.E, that breach induced by payment of expectation damages is moral is a logical conclusion following from my definition of morality of performance. But second, my definition of morality of performance may certainly be questioned. Although I commented above on why it might have appeal, other definitions of morality need to be considered. Let me now turn to the concept of morality in contractual behavior endorsed by Shiffrin.

\section{The Idea that Performance Per Se Has Moral Importance}

Shiffrin finds attractive notions of morality under which there is a special obligation to perform an act stated in the contract, even though she does not offer a precise definition or account of this opinion about moral behavior. She says, "[t]he idea that performance matters is a difficult point to support directly. It is the sort of position toward which one tends to be drawn by instinct rather than led by explicit direction., ${ }^{32}$

In her ensuing discussion, one point that she stresses is that the purpose of a contract is to obtain performance, so that allowing breach and payment of expectation damages would "invert" the true warrant for a contract. ${ }^{33}$ Another point that she advances is that the victim of breach loses his freedom-becoming an involuntary employee of the party in breachbecause the victim has to find a replacement manner of obtaining performance. $^{34}$

I am sympathetic to Shiffrin's views in the sense that I believe that most readers share her intuition that it is wrong to breach a contract, as I discuss in the following Section.

tion, and so on). Any of these issues could, in general, lead to different conclusions about the moral duty to perform.

30. If the moral obligation to disclose information mirrors the functional obligation to perform, there would often, but not always, be a moral duty to reveal information at the time of contracting. For a discussion on economic analysis of contractual disclosure obligations, see Anthony T. Kronman, Mistake, Disclosure, Information, and the Law of Contracts, 7 J. Legal Stud. 1 (1978), and Steven Shavell, Acquisition and disclosure of information prior to sale, 25 RAND J. ECON. 20 (1994).

31. Shiffrin, Breach of Contract, supra note 5, at 1562.

32. Id. at 1564 .

33. Id. at $1565-66$.

34. Id. at 1566 . 


\section{The Choice Among Definitions of Moral Behavior in the Contractual Context}

The debate between Shiffrin and me about the morality of breach of contract can be ascribed primarily to our different definitions of moral behavior. This leads to the question, how might a person choose among competing definitions of such behavior? Let me comment on three criteria by which a definition might be chosen.

First, a definition might be endorsed because it reflects the moral beliefs that individuals actually hold about the moral propriety of breach. My experience, and I suspect the reader's, has been that most individuals react to breach in the way Shiffrin supposes they do, as having an ethically incorrect aspect. Indeed, I conducted a limited survey confirming this hypothesis, ${ }^{36}$ and a recent study by psychologists validates it as well. ${ }^{37}$

Why would individuals tend to hold the view that breach is wrong? The core of the explanation, I believe, is that contractual agreements are seen by individuals as close to, or as even indistinguishable from, promises made in every day life. Such promises are statements that most people think they have a moral obligation to honor. We are taught from childhood that our promises ought to be kept, and this view is reinforced throughout our lives. Thus, it is natural for us to identify contracts with the promises that we have learned to treat as having moral valence. We do not pause to consider that contracts are in fact different from promises made in social intercourse, and that breaking contracts, unlike breaking promises, results in the payment of damages.

Second, a definition of the morality of breach might be selected because it has been developed from certain underlying principles with which one agrees. The definition that I have advanced is partly of this nature, as it is premised on the theory that contracts should be viewed through the lens of hypothetical complete contracts, to which there would be a moral obligation to adhere. I am not sure how to categorize Shiffrin's views, although my conjecture is that they are based on some combination of the first, empirical criterion, and of the second, underlying principles criterion.

Third, a definition of the morality of breach might be chosen because it promotes the welfare of contracting parties. ${ }^{38}$ According to this criterion, my definition of the moral desirability of breach is attractive, for if the definition governs performance-if performance occurs when and only when its

35. These criteria may overlap and are not exhaustive.

36. Shavell, Is Breach of Contract Immoral?, supra note 4, at 452-55. In particular, I found that "the individuals participating in the survey found the simple, unqualified fact of breach to be unethical on average." Id. at 455 . However, when individuals were prompted by being asked to consider the terms of hypothetical complete contracts, they changed their opinions somewhat. Id.

37. Wilkinson-Ryan \& Baron, supra note 1.

38. By the welfare of a party, I refer to the party's expected utility. In strict logic, the utility of a party could depend not only on conventional components of well-being (material goods and services, friendship, and the like) but also on satisfaction of moral notions, but I overlook this latter point for present purposes. 
cost is less than its value-parties will tend to be better off than under any other standard for performance. As the reader knows, if under a proposed contract parties do not perform exactly when cost is less than value, it is always possible to find an alternative contract that both parties would prefer.

Relatedly, a regime of breach and payment of expectation damages promotes the welfare of the contracting parties relative to a regime of required performance. One way of demonstrating this point is to observe that if there is a breach and payment of expectation damages, the buyer is not harmedby hypothesis expectation damages are the equivalent of receiving performance-and the seller is benefited - the seller, after all, chose to commit breach so must have been made better off thereby. In other words, from an ex post perspective, the ability of sellers to commit breach and pay expectation damages benefits them but does not harm buyers. And from an ex ante perspective, the ability of sellers to commit breach and pay damages tends to help buyers affirmatively (rather than merely not to harm them), for sellers can afford to give buyers a price reduction on account of the anticipated benefit derived from their ability to commit breach.

In contrast, Shiffrin seems to believe that a regime permitting breach and payment of expectation damages lowers the welfare of buyers and discourages the making of contracts. She avers that if expectation damages were always paid, "[n]o promisee would ever get what she sought. As a further consequence, if this were the universalized response, then agreements would then never be made. The same is not true if performance were the universalized response to a promise to perform." ${ }^{39}$ This is a perplexing view. As I stated in the preceding paragraph, the buyer is made whole if she receives expectation damages, so she should not be discouraged from contracting under a regime with breach and payment of these damages. Moreover, the seller becomes better off if he can breach and pay damages, so he should be positively encouraged to contract and could share his benefit with the buyer by lowering the contract price. This well-known point from the theory of contracts ${ }^{40}$ helps to explain why contracts flourish under our contract law that permits breach and payment of damages, and also why contracting would be unduly hindered were performance insisted upon as a matter of course.

\section{CONCLUSION}

I have explained in this essay why I think that Seana Shiffrin's criticisms of the pure logic of my article are misplaced. Contracts are, I observed, substantially incomplete, so that a breach of a contract is ordinarily not a violation of an agreement that explicitly mentioned the contingency that occurred. And if one accepts my definition of moral behavior as that which would have been agreed upon in a hypothetical complete contract, it follows that breach and payment of expectation damages is not immoral, because

39. Shiffrin, Breach of Contract, supra note 5, at 1565.

40. See Shavell, Damage measures, supra note 4, at 478 . 
such breaches occur only when performance would not have been specified in a complete contract.

I also asked about the appeal to the moral intuition of my definition of moral contractual behavior. Although I believe that my definition has attractiveness, because it reflects the notion that intended promises should be kept but not unintended ones, I also believe that its virtues can only be appreciated upon reflection. Most individuals seem instinctively to hold a different view, of which Shiffrin's is an exemplar, namely, that breach per se has an immoral dimension. I suggested that the primary explanation for why individuals hold this moral belief is that they regard contracts as simple promises and ignore the incompleteness of contracts-individuals tend to confuse the violation of a contract with the breaking of an explicit promise.

Last, I observed that different criteria may be employed for choosing among definitions of morality: consistency with the moral beliefs found in the population; derivation from favored underlying principles; and the advancement of the welfare of contracting parties. I stressed that according to the welfare criterion, my definition of when breach ought to occur is desirable and that breach and payment of expectation damages raises the wellbeing of both sellers and buyers. Conversely, a moral view under which positive weight is accorded to performance per se works against the interests of both sellers and buyers. 
